\title{
Research on Promotion of the Practice and Education Level of Innovation and Entrepreneurship Based on Red Culture*
}

\author{
Pei Liu \\ Shaanxi Xueqian Normal University \\ Xi'an, China
}

\begin{abstract}
It is necessary to rely on the red culture to combine the new era conditions, focus on the regional politics, industry, culture and other advantageous resources, and inherit the red genes in the innovation and entrepreneurship education and practice. The university should carry forward the political consciousness of "walking in the forefront", integrate the red spiritual traits into the whole process of cultivating innovative entrepreneurial talents, and jointly build a development mechanism of "urban-industry-education" integration. Innovation needs to implement an immersive and collaborative diversified dual-creation talent training model to comprehensively improve the quality of personnel training. It is necessary to forge the soul of the university, inject new elements into the era of the red spirit, and build a red innovation and entrepreneurship education practice system.
\end{abstract}

Keywords-red culture; innovation and entrepreneurship education; practice level

\section{INTRODUCTION}

5,000 years ago, the Chinese and the ancient Egyptians faced the same floods and opened up the world civilization in the middle and lower reaches of the river. 4000 years ago, the Chinese, like the Babylonians, entered the Bronze Age with the use of bronzes. 3000 years ago, the Chinese and the ancient Greeks thought the same and created a group of thinkers who influenced the history of the world. Before 2000, the Chinese, like the Romans, were conquered everywhere, and they expanded their territory and formed a Han nationality on the basis of Huaxia. 1000 years ago, Chinese people were more prosperous than Arabs who were very self-sufficient. Culture and technology entered the most prosperous period of history, and the total economic volume accounted for more than half of the world. The history of more than 5,000 years has created the soul of Chinese culture. Culture is the blood of the nation, the continuation of life, the trace of history, the source of tradition, and the home of the spirit. The inheritance and accumulation of culture allow us to stand on the stage of history with pride.

When the base area was opened up, with the heart of the people, the Communist Party of China awakened the public

*Fund: The teaching reform project of Shaanxi Xueqian Normal University in 2018 "Research on the practice and education level of innovation and entrepreneurship based on red culture" (Project No.: 18JG043Y). with the communist ideals. The new people who won the new China in the flames of gunfire and dedication and sacrifice have created a revolutionary spirit in which the party and the people have a common destiny. On November 25th, 2013, General Secretary $\mathrm{Xi}$ Jinping came to the famous revolutionary old district of Shandong, Linyi, Shandong. He pointed out that "the spirit of Yimeng is the same as the spirit of Yan'an, the spirit of Jinggangshan, and the spirit of Xibaipo. It is a valuable spiritual wealth of the party and the country. It must continue to be carried forward in light of the new conditions of the times." The inheritance of the Chinese higher education to carry forward the spirit of red spirit must run through the whole process of talent cultivation, forging the innovative and entrepreneurial talents who can endure hardship, be good at innovation, dare to take responsibility, and be willing to contribute. [1]

\section{ORGANIC UNITY OF CULTURAL EDUCATION AND INNOVATION AND ENTREPRENEURSHIP EDUCATION}

Cultural education can benefit people for a lifetime. Cultural education aims at the internalization of knowledge and achieves the role of sublimation through internalization, thus allowing educators to form a cultural consciousness. Cultural education is not only the setting and development of several courses, but the internalization and externalization of the whole process and the whole process, thus becoming the spiritual power in the soul. The control of the four aspects of the era of cultural education in colleges and universities cannot be ignored: First, universities should deal with the relationship between market demand and the purpose of cultural education. The purpose of school education is to shape personality, rather than blindly cater to the needs of the market. The second is to deal with the relationship between the construction of the superstructure and the law of cultural education. The talents to be cultivated in colleges and universities are both capable and moral, rather than just pursuing economic growth and neglecting the spiritual construction. The third is to deal with the relationship between dedication and cultural character, and focus on cultivating students' noble character and serving the society. The fourth is to deal with the relationship between natural selection and humanistic concern, both to give students love and care, but also to establish students' sense of competition. 
China is in a critical period of achieving the strategic goal of modernization. The development of society and economy puts high demands on the cultivation of innovative and entrepreneurial talents. History proves that the Communist Party of China is the best innovation and entrepreneurial team in the history of mankind. New China is the biggest innovation and entrepreneurial achievement in human history. Xi Jinping served as a party branch secretary in Liangjiahe, and he has worked hard and hard, and has achieved a brilliant and innovative example of great character. These facts need to be used to educate teachers and students to learn from the revolutionary ancestors. It is necessary to call on teachers and students to study General Secretary Xi Jinping and bear in mind the teachings of the General Secretary "Hardship makes perfect man". The development of China today is booming. In this era of cultural self-confidence, colleges and universities, as a model of stability and unity under the leadership of the party, not only bear the responsibility of the transmission of cultural knowledge, but also a strong position for cultural education. Nowadays, young students are enthusiastic, innovative, and easy to fluctuate. Therefore, schools should strengthen the cultural education of young people, pay attention to the influence of cultural education, and let young scholars have correct thinking and firm cultural self-confidence, so that they can truly shoulder the burden of building a socialist cause.

The unwavering communist conviction in the spirit of red culture is the essence of all Chinese Communists. It is precisely because of this conviction that China has achieved worldrenowned achievements, built a new China with socialism with Chinese characteristics, and gradually realized the great rejuvenation of the Chinese nation. What the country needs to create is the big cause of the country, and the college students create a small undertaking for college students. Like the river into the sea, these small businesses have become a big cause of the country. Therefore, the innovation and entrepreneurship of college students must also draw spiritual strength from communist beliefs. Once the goal is established, college students must make up their minds and unswervingly take the road of innovation and entrepreneurship.

The spirit of collectivism in the spirit of red culture is another spiritual weapon for the Chinese Communist Party to achieve a revolutionary victory. In the war years, the Communist Party of China relied on the spirit of collectivism to become a force that scared the enemy. In the era of peace, the Communist Party of China broke through various shackles by the spirit of collectivism and achieved remarkable results in the world, transforming from a regional power to an international power. Innovation and entrepreneurship can be successful without relying on individuals, but with teams. Therefore, in the process of innovation and entrepreneurship, college students should learn the spirit of collectivism from martyrs and predecessors, and make the road to innovation and entrepreneurship more stable and smoother.

The spirit of hard struggle in the spirit of red culture is a spirit of struggle. Not afraid of hardship and overcoming difficulties are the fine traditions of the Chinese Communists and the tradition of the Chinese nation. It is in this spirit that for thousands of years, the Chinese nation can survive through the vicissitudes of life and stand in the forest of the nations of the world. In response to the call of the state, the group of college students who are independent innovation and entrepreneurship, as the successor of socialism and the practitioners of state policies, should continue to carry forward the spirit of hard work, don't fear the hardships and difficulties of the entrepreneurial road, meet the challenges, and contribute to the national construction cause.

The spirit of innovation in the spirit of red culture is the key to the success of revolution and construction, and the soul of red culture. The spirit of innovation in the spirit of red culture includes the pioneering spirit of pioneering and daring, the spirit of change and struggle, the spirit of innovation and the spirit of self-purification. Innovation in red culture is broader, hierarchical and realm than innovation in innovation and entrepreneurship education. In order to innovate and start a business, college students must dare to explore, take the initiative to change, and constantly break through the self, in order to create more results with social value.

\section{IT IS NECESSARY TO USE COMPETITION TO PROMOTE EDUCATION}

The "13th Five-Year Plan" proposes to stimulate the innovation and entrepreneurial vitality of colleges and universities and promote public entrepreneurship. Many universities in China have successively held various innovation and entrepreneurial competitions, setting off a wave of innovation and entrepreneurship. At present, governments at all levels attach great importance to innovation and entrepreneurship, and have introduced a series of policies that are conducive to college students' innovation and entrepreneurship. Local colleges and universities can combine the red culture to carry out the innovation and entrepreneurship contest, take the big game as an opportunity, rely on the red resources to focus on the innovation and entrepreneurship, establish an innovation and entrepreneurship incubation base, etc., and carry out innovation and entrepreneurship education. To a certain extent, this measure can not only train students to innovate and innovate, but also promote the development of red resources. Through the Innovation and Entrepreneurship Competition, college students will further explore red cultural resources. This further stimulates college students' enthusiasm for innovation and entrepreneurship, allowing them to find deficiencies in the practice process, exercise entrepreneurial ability, and cultivate innovative spirit. In addition, the participating teams can also enter the revolutionary old district to help the people in the old district get rid of poverty and become rich and help the economic and social development of the old revolutionary areas.

It is necessary to analyze and clarify the "short" and "pain points" of colleges and universities, find "demand points" and "points of interest" of social institutions, explore ways to connect with social institutions, and find the "combination point" of cooperation between government, universities and social institutions. In the process of cooperation between government, universities and social institutions, China's higher education actively understands the needs of social institutions, actively connects resources, and explores the combination and best ways of cooperation. They actively stimulated the momentum of all parties, implemented the integration of 
"production-teaching", built a community of "co-existence and common prosperity", built a platform for innovation and entrepreneurship, and implemented the integration of schools, localities, science parks and enterprises, achieving multi-win. [2]

\section{INTEGRATING "INNOVATION AND ENTREPRENEURSHIP" EDUCATION INTO TALENT TRAINING}

Innovation and entrepreneurship education is a bilateral teaching activity composed of teachers' teaching and students' learning. It is necessary to adhere to the essential orientation of people-oriented education. The red cultural resources are the precious spiritual wealth of the Chinese nation. The red atmosphere strengthens the responsibility and identity of college students, the red gene strengthens the sense of responsibility of college students, and the red spirit guides the choice of responsible behavior of college students. Local colleges and universities can refine the elements of innovation and entrepreneurship in the red culture, organically integrate the red culture in the innovation and entrepreneurship curriculum, strengthen the innovative and entrepreneurial spirit of the arduous struggle of college students, cultivate their unshakable entrepreneurial beliefs, and guide students to establish the correct entrepreneurial concept. Red culture must not only be integrated into the ideological and political lessons of local colleges and universities. As an ideological and political theme, it is necessary to dig out the important elements of red culture for innovation and entrepreneurship education, and integrate it into the curriculum system of innovation and entrepreneurship education in local universities. For example, the red story in the red culture can be incorporated into the textbook of innovation and entrepreneurship education, and the red culture education course can be used as an elective course to open a red culture forum and special lectures. Through the classroom to cultivate students' arduous struggle quality, practice innovation spirit, team awareness, etc., college students' innovation and entrepreneurial awareness are strengthened to adapt to the rapid development of modernization needs.

Schools should focus on guiding students to adopt relevant areas (subject), industry (professional) knowledge, technology and experience to put good entrepreneurial aspirations into practice. Deepen entrepreneurship education, the breakthrough is to gradually integrate entrepreneurship education into the education of related majors. The school builds a model of immersive and collaborative diversified talents with distinctive characteristics, integrates innovation and entrepreneurship into the whole process of talent cultivation, and comprehensively enhances the quality of personnel training. The students' innovation and entrepreneurial ability have improved significantly, and the employment and entrepreneurship rate has stabilized at around 95\%. [3]

At present, the focus of the innovation and entrepreneurship education system in colleges and universities is on awareness training, ability improvement, environmental cognition and practice simulation. Among them, only awareness training is to mentally prepare students for innovation and entrepreneurship. The training form is mainly the teacher's conceptual explanation and case interpretation of the innovation consciousness and innovative spirit from the theoretical perspective through the innovation and entrepreneurship education curriculum, so that students can understand the quality requirements of innovative talents. This kind of innovation and entrepreneurship education system is obviously lacking, and it cannot fundamentally meet the ideological and spiritual needs of innovative and entrepreneurial students. The spirit of diligence, bravery, pioneering spirit, teamwork, hard work, innovation and selfless dedication in the spirit of red culture is necessary in the process of innovation and entrepreneurship. Therefore, the spirit of red culture will be a very important supplement to the innovation and entrepreneurship education system of colleges and universities, and also an inevitable requirement for improving the innovation and entrepreneurship education system. [4]

\section{CONCLUSION}

"Promoting red culture and inheriting red genes" requires students to truly feel the charm of red culture, establish ideals and beliefs, enhance cultural identity, and establish correct values without being impacted by multiculturalism. It is necessary to innovate cultural media to integrate red culture with campus culture and innovation and entrepreneurship education through classrooms, associations, volunteers, cultural and sports activities, and to make the campus full of red culture. The red culture can be spread through a rich form of communication, such as the "campus red film column", which allows students to understand the red culture more intuitively through images. "Lecture on the theme of red culture" promotes the red culture while promoting the quality and abilities of the students through the theme. "Telling red stories and singing red songs" is provided through a rich form of literary and artistic activities, showing the era of college students in the new era, inheriting the red classics. The red classics are passed down from generation to generation, which makes the red culture influence the behavior and behavior of college students in the subtle influence, internalizing in the heart and externalizing in behavior. [5]

Relying on the red culture and combining the new conditions of the times, the university constantly integrates the red spirit and culture into the daily education and teaching activities, inherits the red genes in the innovation and entrepreneurship education and practice, and carries forward the political consciousness of the university "going in the forefront". The university integrates the red spiritual traits into the whole process of cultivating innovative and entrepreneurial talents, innovates and implements the immersive collaborative diversified dual-creative talent training model, and comprehensively improves the quality of talent training. According to the teacher's characteristics of Shaanxi Xueqian Normal University, the school has continuously built a red innovation and entrepreneurship education practice system, cultivated more talents for the teacher-class majors, and at the same time improved the level of dual-creation teachers, thereby constructing a teacher-class innovation and entrepreneurship education system based on red culture. 


\section{REFERENCES}

[1] Xu Yan. The study of Sichuan red culture spirit blending into the innovation and entrepreneurial quality cultivation of higher vocational college students. [J]. Comparative Study of Cultural Innovation, 2019, 3 (23): 60-61. (in Chinese)

[2] Peng Hongjun, Peng Peng, Ayedana kusprati, Lu Zesen, Jiang Yujia. Holding up the banner of Yimeng spirit to build a red innovation and entrepreneurship system - Taking Linyi University as an example [J]. Education Modernization, 2019, 6(58): 34- 35+87. (in Chinese)

[3] Sun Min. Mining red cultural values and inheriting the spirit of red culture [N]. Guilin Daily, 2017-11-05 (002). (in Chinese)

[4] Jiang Xuelian. On the innovative spirit of red genes [J]. Beijing Education: Moral Education, 2018 (4): 76-79. (in Chinese)

[5] Feng Qingyuan, Wang Juan. Research on the cultivation path of higher vocational college students' entrepreneurial quality based on the perspective of entrepreneurship education - Taking Changzhou higher vocational education park as an example [J]. The Guide of Science \& Education: late, 2018 (5): 171-172. (in Chinese) 